\title{
The Autecology of Genus Dischidia (Asclepiadaceae) in Bangka Island: Characteristics of Vegetation and Abiotic Environmental Factors Affecting Abundance
}

\author{
Yuliani Hajari, Sulistijorini *, Nunik Sri Ariyanti \\ Department of Biology, Faculty of Mathematics and Natural Sciences, Bogor Agricultural University, Bogor \\ 16680, Indonesia
}

Article history:

Submission December 2017

Revised January 2018

Accepted February 2018

*Corresponding author:

E-mail: ssulistijorini@gmail.com

\begin{abstract}
Dischidia is an epiphytic plant, it is used as herbal medicine and has economic value. In addition, Dischidia also has an ecological function. Moreover, some species of Dischidia are endemic in a particular region. Various forest types occur in Bangka Island serves as natural habitat for this epiphytic plant. This research aimed to record the diversity and abundance of Dischidia and analyze those environmental factors which affect its abundance. The research was conducted in August - September 2016 at Bangka Island. Three plots of $20 \times 20 \mathrm{~m}^{2}$ were placed with a minimum interval of $50 \mathrm{~m}$ in the habitat where Dischidia are found. The species diversity and abundance of Dischidia as well as abiotic factors such as temperature, humidity, light intensity, wind speed, and altitude were recorded in these plots. The vegetation structure was analyzed based on index of diversity, index of dominancy and index of evenness. Data on the environmental condition and abundance of Dischidia were then analyzed using Canonical Correspondence Analysis (CCA) method with Canoco 4.5 software. Five species of Dischidia were found in Bangka Island that are Dischidia bengalensis, Dischidia imbricate, Dischidia nummularia, Dischidia rafflesiana, and Dischidia hirsute. Dischidia is found in 14 species of host plants. D. imbricate (23 individual plants) occurred in the heath forest at Pejem showed the highest abundance. Epiphytic fern plants, the Asplenium nidus (27 individual plants), was the dominant epiphytes found in the host tree of Dischidia The CCA showed that light intensity, temperature and humidity influenced the abundance of Dischidia.
\end{abstract}

Keywords: Bangka Island, Dischidia, environmental factors, epiphyte

\section{Introduction}

Dischidia, is one of epiphytic plant genus in the family of Asclepiadaceae, consists of 80 species which are native to tropic and sub tropic area in Asia. It is closely related to another epiphytic genus in the Asclepiadaceae the Hoya [1]. Dischidia does not have root beneath the ground. Therefore, this plant twists its body on another plant [2] or form a hanging huge mass on the host plant [1].

Some of Dischidia can be utilized as a medicine; Dischidia pectinoides are used for a breathlessness [3]. Another species, Dischidia imbricate contains some secondary metabolites such as alka- loids, flavonoids, and steroids or triterpenoids which enable to serve as an anti-cancer and antitumor [4]. Moreover, Dischidia also has an ecological function; Dischidia major has mutualism with ant, Lasius fuliginosus which has storage inside of the leave of $D$. major which is used for nurturing the larva and accumulating organic debris that will be used by $D$. major as a source of nitrogen [5]. In addition, Dischidia has potential to be an ornamental plant; Dischidia hirsute is one of ornamental species which has high economic value [6].

In some countries such as Philippine and New Guinea, some species of Dischidia are endemic

\section{How to cite:}

Hajari Y, Sulistijorini, Ariyanti NS (2018) The Autecology of Genus Dischidia (Asclepiadaceae) in Bangka Island: Characteristics of Vegetation and Abiotic Environmental Factors Affecting Abundance. Journal of Tropical Life Science 8 (3): 269 - 278. doi: 10.11594/jtls.08.03.09 
species. Dischidia torricellensis is endemic in New Guinea, and Dischidia cleistantha is only found in Philippine [7]. Dischidia grows in lowland forests $(0-600$ masl) and mountain forests. The species Dischidia bengalensis requires full light, therefore this species grows in lowland forests on the canopy open with an elevation of 600 masl. Whereas, Dischidia lanceolata is found on altitude of 1300 - 2000 masl in humid forests of Sumatra and Lombok. Dischidia nummularia grows in mountain forests in West Java at an altitude of 1300 - 1800 masl [8].

Several species of Dischidia are categorized from their vulnerability to the endangered condition, but data pertaining to their ecological status remains limited. Dischidia acutifolia is listed as critically endangered plant in Singapore [9]. Dischidia litoralis was listed as a category of vulnerable in Queensland by the rare and endangered Nature Conservation Act (1992) by The National Red List 2012. Besides, D. nummularia is also categorized as critically endangered by The Nasional Red List 2012 of Sri Lanka [10].

Bangka Belitung is one of the archipelago provinces in Indonesia. It is located on the eastern Sumatera across South Sumatera province. One of the main islands of the province is Bangka Island. Some of the forests on this island belong to the heath forest [11], a unique natural vegetation found only in Bangka Belitung Island and a small part of Kalimantan. These forest characters are sandy soils, acidic, and poor nutrients [12], thus causing a different flora compared to other lowland rainforests. Currently, three quarters of the island of Bangka is a tin mining area that threatens the sustainability of the forests. Tin mining has impacts on the destruction of natural landscape and natural habitat for biodiversity [14] including the diversity of Dischidia species. The impact of this damage is feared reduce the number of plant species. It is therefore necessary to search the diversity and abundance of Dischidia, and it is hosts, other epiphytic plants associate with Dischidia as well as the environmental factors affecting the abundance of it.

\section{Material and Methods}

\section{Time and locations}

This research was conducted during August September 2016 on 12 locations which distributed in four districts of Bangka Island: Toboali and Koba (South Bangka Regency), Nangka Island and Sungaiselan (Central Bangka Regency), Pejem, Kemuja, Riausilip, Petaling, Mangkol, Bakam, and Pemali (Bangka Regency), Mentok (West Bangka Regency).

\section{Location plotting}

The research locations were determined by exploring the secondary forests, heath forests and lowland tropical rain forests in four districts in Bangka Island to obtain the distribution location of Dischidia.

\section{Sampling methods}

Three plots measuring $20 \mathrm{~m} \times 20 \mathrm{~m}$ were placed by a purposive sampling with a minimum interval of $50 \mathrm{~m}$ in the habitat where Dischidia is found. Specimen Dischidia was collected and made as herbarium by following the previous specimen collecting method [15]. The amount and names of the host tree species of Dischidia in the plot were calculated and recorded. In addition, bark texture, roughness, and $\mathrm{pH}$ of bark were also recorded. The type and number of individual by Dischidia and other epiphytes in each host tree were also recorded.

Data coordinates of location where the Dischidia species occurred were taken used GPS map Garmin 62s. Climatic data (micro climate) were measured on the plot: the light intensity by using lux meters, the wind speed and humidity by using hand-land 4 in 1 environmental meter, the air temperature determined using thermohigrograph.

\section{Vegetation structure analysis}

Plots of nested quadrat method were used for analyzing the composition (density and dominance) of vegetation of different stage: $20 \times 20 \mathrm{~m}^{2}$ for tree, $10 \times 10 \mathrm{~m}^{2}$ for pole, $5 \times 5 \mathrm{~m}^{2}$ for sapling, $2 \times 2 \mathrm{~m}^{2}$ for seedlings, shrubs, and ground cover plants.

\section{Environmental data and analysis of Dischidia vegetation structure abundance}

Data were analyzed to describe the vegetation structure of the habitat of Dischidia based on several parameters: Shannon Wienner index $\left(\mathrm{H}^{\prime}\right)$ [16], Evennes index (E), and Dominance index (D) [17]. Environmental data and Dischidia abun- 


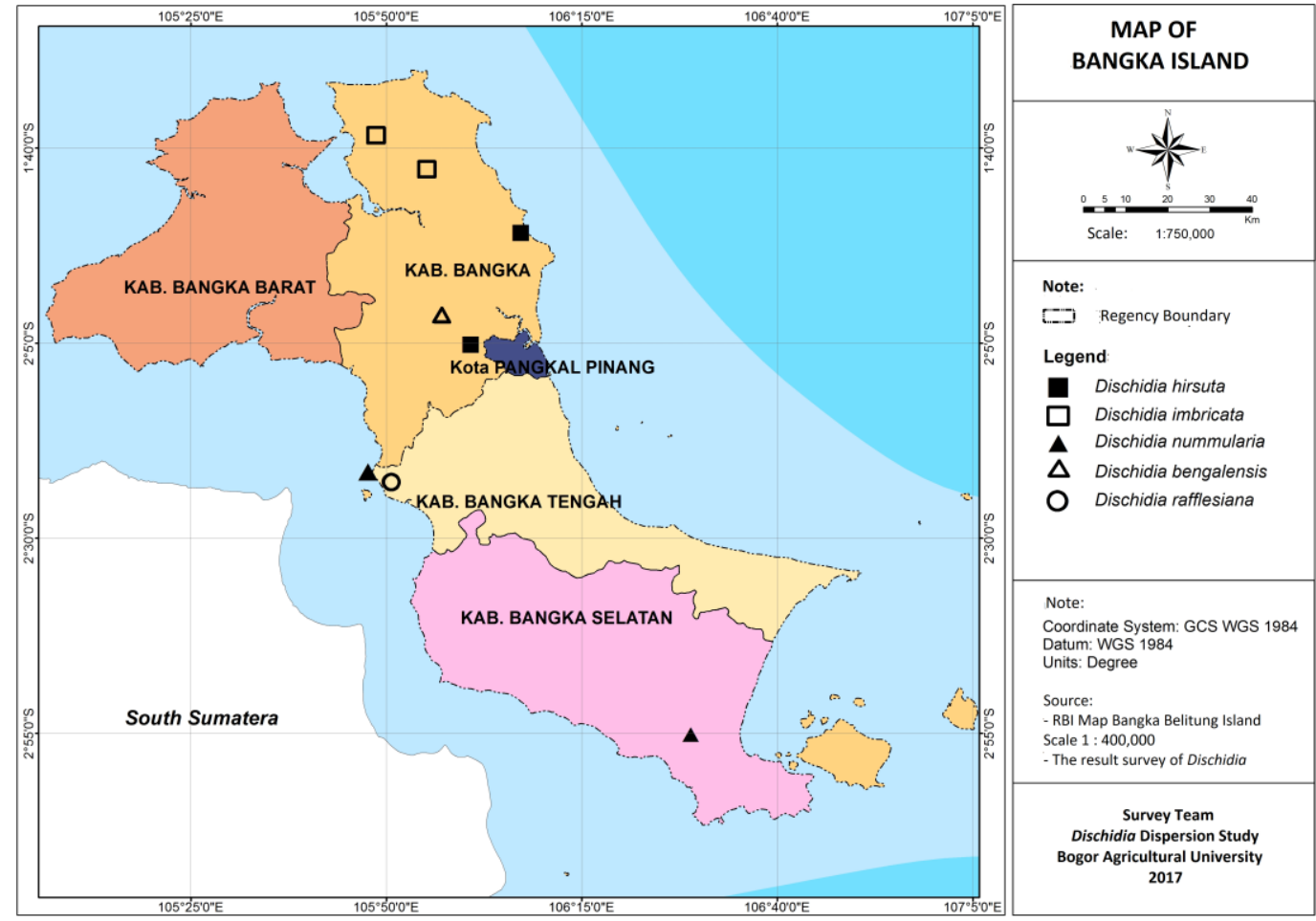

Figure 1. Map showing distribution of Dischidia species in Bangka Island

Table 1. Abundance of Dischidia species (number of individuals in 3 plots $20 \mathrm{~m} \times 20 \mathrm{~m}$ ) in their habitat at seven sites in Bangka Island

\begin{tabular}{lllc}
\hline \multicolumn{1}{c}{ Location } & Type of vegetation & Species & Number of individuals \\
\hline Pejem (Central Bangka) & Heath forest & D. imbricate & 23 \\
Nangka Island (Bangka) & Heath forest & D. rafflesiana & 2 \\
& Heath forest & D. numularia & 4 \\
Toboali (South Bangka) & Secondary forest & D. numularia & 2 \\
Riausilip (Bangka) & Secondary forest & D. hirsute & 5 \\
Petaling (Bangka) & Secondary forest & D. hirsute & 2 \\
Kemuja (Bangka) & Secondary forest & D. bengalensis & 7 \\
Mangkol (West Bangka) & Secondary forest & D. hirsute & \\
\hline
\end{tabular}

dance were analyzed by Canoco for windows 4.5 software with RDA method [18]. This analysis was used to determine the relationship between light intensity, wind speed, humidity, temperature, and altitude of Dischidia abundance.

\section{Results and Discussion}

\section{Diversity of Dischidia}

The exploration of Dischidia was conducted on 12 locations which is distributed in four districts of Bangka Island. Dischidia populations were found in seven locations, i.e Toboali (South Bangka Regency), Nangka Island (Central Bangka Regency), Pejem, Kemuja, Riausilip, Petaling and
Mangkol (Bangka Regency) (Figure 1). Exploration in five other locations, i.e. Bakam and Pemali (Bangka Regency), Sungaiselan (Central Bangka Regency), Koba (South Bangka Regency, and Mentok (West Bangka Regency) did not find the population of Dischidia. In this current study, five species of Dischidia were found. However, only one species of Dischidia was found in each explored location, except for Nangka island in which found two species, D. rafflesiana and D. nummularia (Figure 1).

The species D. rafflesiana was found only on the Nangka island. Dischidia distribution in Bangka island is mostly found in Bangka Induk Regen- 


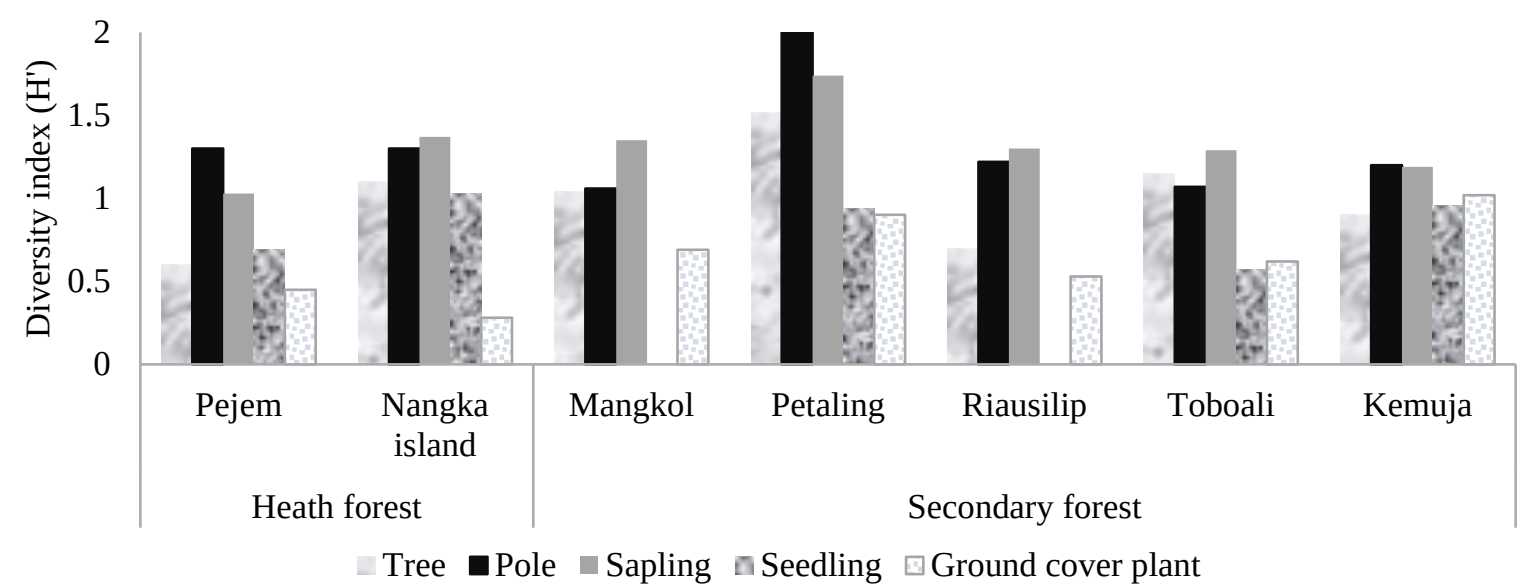

Figure 2. Diversity index ( $\left.\mathrm{H}^{\prime}\right)$ at the research sites on Bangka Island on trees, poles, sapling, seedlings and ground cover plants

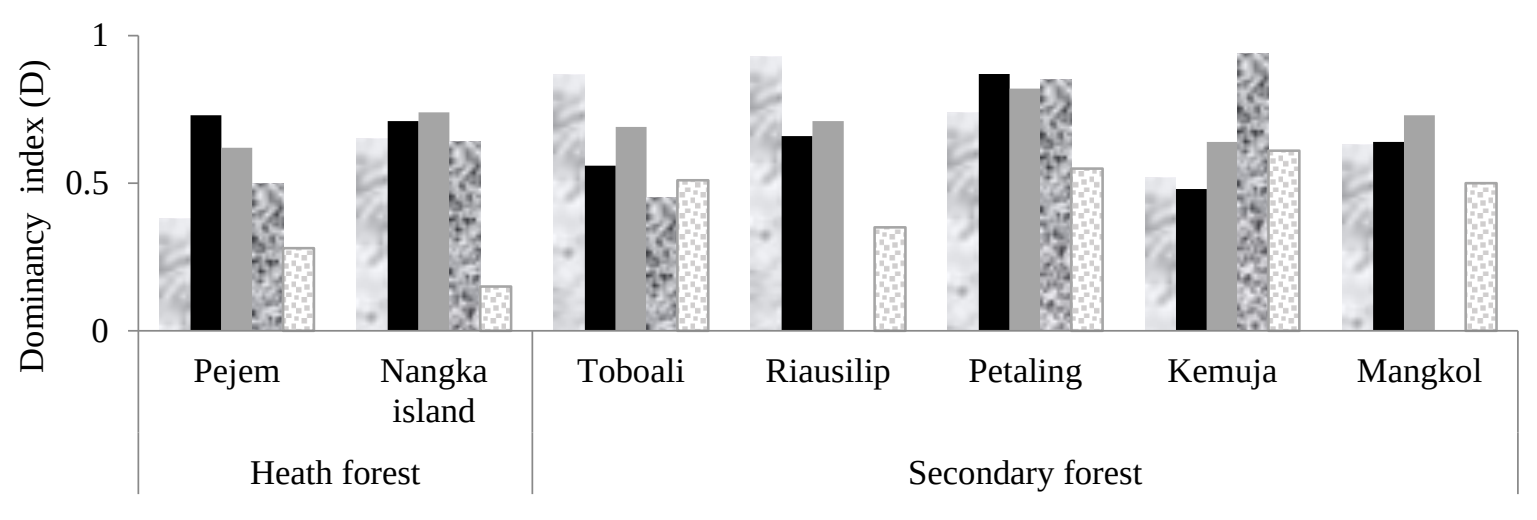

Tree $\square$ Pole $\square$ Sapling $₫$ Seedling $₫$ Ground cover plant

Figure 3. Dominance Index (D) at the research sites on Bangka Island on trees, poles, sapling, seedlings and ground cover plants

cy which is in four locations with total diversity of 5 species. The Dischidia species previously reported in Indonesia are D. acutifolia (Borneo, Java, Sulawesi, Sumatra), Dischidia albida (Borneo, Sulawesi, Sumatra), Dischidia asthepana (Borneo), D. bengalensis (Borneo, Java, Sulawesi, Sumatra), D. hirsute (Borneo, Sumatra, Java, Sulawesi), D. lanceolata (Java), D. imbricate (Borneo, Java, Sumatra), Dischidia latifolia (Java), D. major (Borneo, Sulawesi, Sumatra, Java) [19].

\section{The abundance of Dischidia in the habitat}

$D$. rafflesiana was found in the heath forest, while $D$. hirsute and $D$. bengalensis were spotted in secondary forests. $D$. numularia and $D$. imbricate were found in secondary forests and heath forests. The abundance of Dischidia in the heath forest is higher than in the secondary forest. $D$. imbricate, the most abundant species (23 individu- als), was found in the Pejem heath forest. A total of 14 individuals from two species Dischidia were found in the heath forest of Nangka island. The Dischidia that is found in secondary forest was only 2- 7 individuals (Table 1). Dischidia in the heath forest tended to be abundant because this forest was categorized as an opened forest with high light intensity. Generally, Dischidia lives in opened forests with high light intensity [19].

\section{Vegetation structure of Dischidia Diversity index (H')}

Biotic factors that may capable of affecting the presence of Dischidia is the vegetation structure. Based on the Shannon Wienner ( $\left.\mathrm{H}^{\prime}\right)$ Diversity Index in all researches, the highest H' value was attributed to tree strata (1.52), pole (2), sapling (1.74) in secondary forest of Petaling, seedling (1.03) in heath forest of Nangka island and ground 
cover plants (1.02) in secondary forest of Kemuja. The lowest $\mathrm{H}$ value was attributed to tree (0.6) in the Pejem heath forest, pole (1.06) in secondary forest of Kemuja, sapling in secondary forest of Riausilip (1.03), seedlings (0) in secondary forest of Mangkol and Riausilip and ground cover plants (0.28) in the secondary forest of Nangka island. The secondary forests of Petaling have higher diversity, with exception in that the lower seedling and ground cover plants strata of the secondary forest (Figure 2).

Secondary forests in Mangkol and Riausilip have lower diversity in comparison with other sites in both secondary forests and heath forests in all strata. The low value of $\mathrm{H}^{\prime}$ in the forest was caused by the low composition of tree species vegetation in this forest because some species could replace other species (redundant) [20].

The vegetation in heath forest was dominated by Myrtaaceae (Tristaniopsis and Baeckea frutescens), and several species of Melastomataceae. In the forest, the growth rate from tillers to adulthood was slow [20]. The soil condition of heath forest is nutrient-poor, thus only certain species could reach their optimum growth in such condition.

\section{Dominance index $(C)$}

The dominance index for all strata in all locations ranged from 0 to 0.94 . The highest value was attributed to seedling strata (0.94) in secondary forest of Kemuja, while the lowest value was attributed to seedlings (0) in secondary forest of Riausilip and Mangkol (Figure 3). The high dominance index indicates that the place has a low diversity and an uneven distribution. The presence of dominance demonstrates that not all plants have the same adaptation.

\section{Evenness index (E)}

Distribution of a balanced plant if it has an evenness index values ranging from 0.6 to 0.8 [16]. The highest evenness (E) values were found in the tree (0.98) in the heath forest of Nangka islands, the pole (0.98) in the secondary forest of Petaling, the weaning (0.97) in the secondary forest of Mangkol and Petaling, the seedling (1) in the heath forest Pejem and undergrowth strata in secondary forest Mangkol. The lowest E values for the tree (0.67) in the secondary forest of Riausilip, the pole (0.77) in secondary forest Kemuja, sap- ling (0.85) in the Toboali secondary forest, the seedling in the secondary forests of Mangkol and Riausilip, and the ground cover plant (0.4) in the heath forest of Nangka islands. The strata of trees and columns for all locations showed a steadystate deviation of $>0.6$ [21]. This indicated that the sustainability of species diversity in both stands was properly maintained. The high strata of trees and poles are favorable for epiphytic plants because supplies for the host are high.

\section{Microclimate conditions of Dischidia habitat}

The microclimate condition of secondary forests and heath forests was dissimilar. The average temperature in both observation sites was recorded from $31^{\circ} \mathrm{C}$ to $37.5^{\circ} \mathrm{C}$. The highest average air humidity value reached $79.4 \%$ in secondary forest of Mangkol. The highest light intensity was recorded on the heath forest of Pejem (2036.5 Lux). Habitat conditions in the location were quite open and very close to the beach, leading to higher temperature. Additionally, heath forest was observed to have higher wind speed compared to secondary forest $(1.3 \mathrm{~km} / \mathrm{s})$. Heath forest seems to have sparse population of the trees, thus enhancing the wind speed, as presented in (Table 2).

The CCA analysis (Figure 5) shows the correlation of environmental factors to the abundance of Dischidia plant. Abundance D. rafflesiana was affected by wind speed. Dischidia were found in the heath forest having specific conditions such as more open condition and close to the beach. However, another species such as $D$. bengalensis was more affected air humidity. Furthermore, Dischidia was also found in secondary forests having more closed habitats. D. hirsute, D. imbricate, and $D$. nummularia were excluded from cluster of the observed environmental variables because they were general species.

\section{Host availability for Dischidia}

The results showed that available host of pole strata was higher than that of tree strata, except for Nangka island and Toboali. Dischidia was more found in host pole strata (21 individual hosts) than tree strata (13 individual hosts) (Table 3).

\section{Diversity of Dischidia host}

Dischidia was found in 14 species of host plants. The diameter of the host tree Dischidia ranged from 13.6 to $45.5 \mathrm{~cm}$. The Dischidia grew 


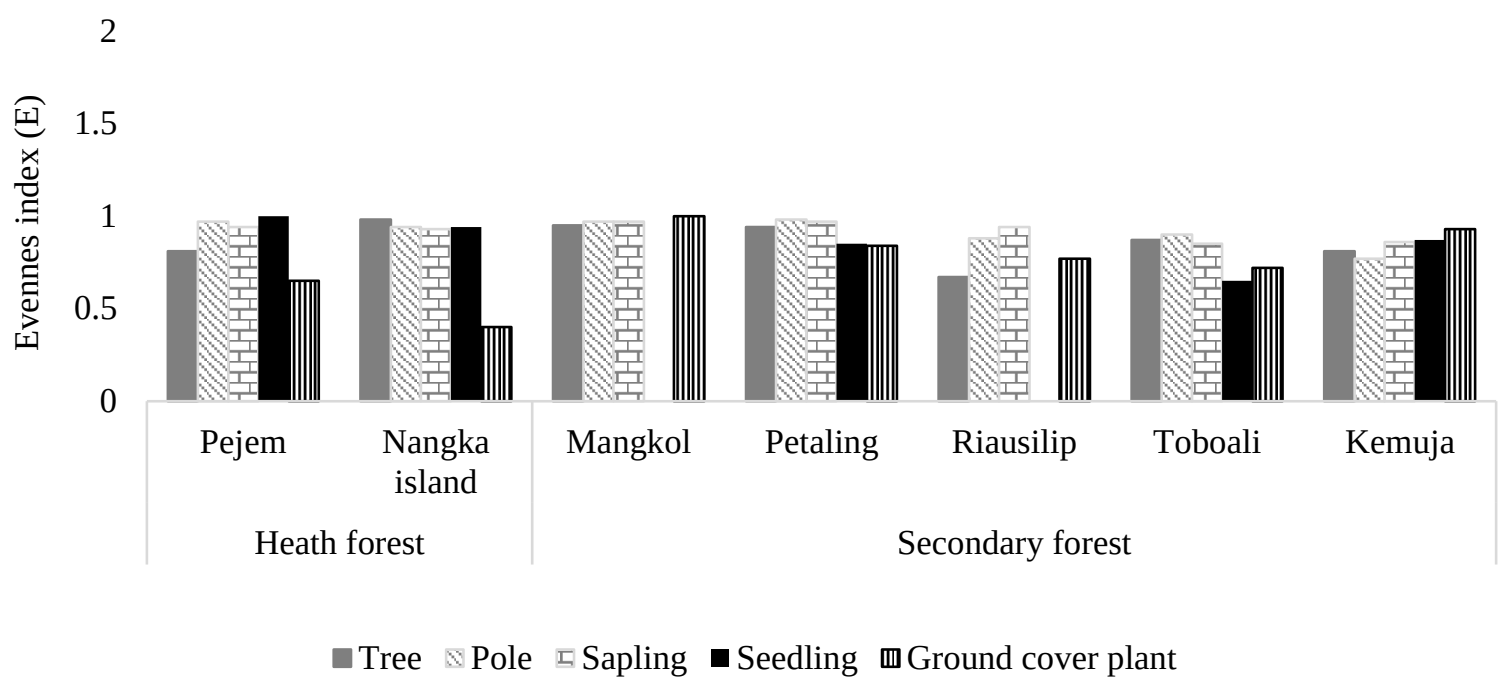

Figure 4. The evenness index (E) at the research sites on Bangka Island on trees, poles, sapling, seedlings and ground cover plants

Table 2. Type of vegetation and microclimate conditions of Dischidia habitat in seven locations on Bangka Island

\begin{tabular}{llccccc}
\hline \multirow{2}{*}{$\begin{array}{c}\text { Type of } \\
\text { vegetation }\end{array}$} & \multirow{2}{*}{ Location } & Altitude (masl) & \multicolumn{4}{c}{ Microclimate } \\
\cline { 4 - 7 } & & & IC (Lux) & KA (km/s) & RH $(\%)$ & T $\left({ }^{\circ} \mathrm{C}\right)$ \\
\hline Heath forest & Nangka island & 10 & 1927 & $1.2-1.3$ & 67.1 & 35.2 \\
Heath forest & Pejem & 27 & 2036.3 & $0.2-0.3$ & 57.6 & 37.5 \\
Secondary forest & Toboali & 43 & 1250 & 0.12 & 78.2 & 31 \\
Secondary forest & Riausilip & 52 & 1353.3 & 0 & 78.6 & 33.1 \\
Secondary forest & Petaling & 120 & 1323.3 & 0 & 69.3 & 33.7 \\
Secondary forest & Kemuja & 132 & 1370.6 & $0.16-0.2$ & 79.3 & 32.1 \\
Secondary forest & Mangkol & 379 & 1250 & $0.2-0.3$ & 79.4 & 31.1 \\
\hline
\end{tabular}

Note: $\quad$ IC= light intensity; KA= wind speed; RH= humidity; $\mathrm{T}=$ temperature

on the branch and or main stem with a host height of $0.6-8 \mathrm{~m}$ (Table 4). The tree enables to improve growth of epiphytes which need sunlight. $D$. imbricate and $D$. rafflesiana are species found with the highest host elevation.

D. imbricate was found in 9 individual hosts of the species $B$. frutescens, and each individual host of the Acacia sp., Artocarpus heterophyllus and Theobroma cacao species. Each host species has an individual Dischidia except on B. frutescens with 19 individuals and Acacia sp. with 4 individuals Dischidia. D. imbricate is found in the host on the tree and/or pole strata $(5.8-26.6 \mathrm{~cm})$ with the average height of Dischidia position at the host $5 \mathrm{~m}$. D. nummularia is found in a host of Durio zibethinus and three hosts of Mangivera indica, with $3-4$ individuals of Dischidia in each host. The previous research reported that species
D. nummularia was found in Mangivera sp. and Tectona sp. which often attached as epiphytic plants [22]. D. nummularies was found in hosts with tree strata $(38.5-45.6 \mathrm{~cm})$ with a height of 4 $-7 \mathrm{~m}$.

The results CCA of the analysis between the abundance of Dischidia and the characteristics of the host tree showed that $D$. rafflesiana and D. imbricate correlated positively with growth location (F-ratio = 0.93; P-value $=0.47)$. Species $D$. nummularia and $D$. imbricate correlated significantly with roughness $($ F-ratio $=0.7 ; \mathrm{P}$-value $=0.57$ ). Species $D$. bengalensis and $D$. hirsute were positively correlated with skin $\mathrm{pH}($ F-ratio $=2.81$; Pvalue $=0.02$ ) (Figure 5$)$. The highest correlation level is the $\mathrm{pH}$ of the bark because of the value $0.05<$ P-value $>$ F-ratio. Dischidia was found in bark with pH 6.7 - 7. Epiphytic plants live on bark 
Table 3. Total availability of substrate ( $\Sigma$ tree and $\Sigma$ pole) and host availability of Dischidia in 3 plots $20 \mathrm{~m} \times$ $20 \mathrm{~m}$

\begin{tabular}{|c|c|c|c|c|c|c|}
\hline \multirow{2}{*}{ Location } & \multicolumn{2}{|c|}{$\sum$ available host } & \multicolumn{2}{|c|}{$\Sigma$ host on board Dischidia } & \multirow{2}{*}{$\Sigma$ individual } & \multirow{2}{*}{ Species name } \\
\hline & Tree strata & Pole strata & Tree strata & Pole strata & & \\
\hline \multirow{2}{*}{$\begin{array}{l}\text { Nangka } \\
\text { island }\end{array}$} & \multirow[t]{2}{*}{13} & \multirow[t]{2}{*}{12} & 1 & 4 & 2 & D. rafflesiana \\
\hline & & & 1 & - & 4 & D.nummularia \\
\hline Pejem & 8 & 11 & 2 & 8 & 23 & D. imbricate \\
\hline Toboali & 11 & 10 & 3 & - & 8 & D.nummularia \\
\hline Riausilip & 13 & 28 & 1 & 1 & 2 & D. hirsuta \\
\hline Petaling & 19 & 31 & 3 & 2 & 5 & D. hirsuta \\
\hline Kemuja & 14 & 42 & - & 2 & 2 & D. bengalensis \\
\hline Mangkol & 8 & 14 & 2 & 4 & 7 & D. hirsuta \\
\hline Number & 86 & 148 & 13 & 21 & 53 & \\
\hline
\end{tabular}

Table 4. Species diversity and features of host stem and Dischidia position on host

\begin{tabular}{|c|c|c|c|c|c|c|c|c|}
\hline Dischidia species & Location & Host species & $\Sigma$ host & $\mathrm{D}(\mathrm{cm})$ & $\mathrm{pH}$ & TK & $\mathrm{TP}$ & LT \\
\hline \multirow[t]{2}{*}{ D. nummularia } & Toboali & M. indica & 3 & 75.6 & 7 & 3 & 4 & 1 \\
\hline & Nangka Island & D. zibethinus & 1 & 83.5 & 6.9 & 2 & $6-7$ & 1 \\
\hline \multirow[t]{4}{*}{ D. imbricate } & Pejem & B. frutescens & 9 & 18.2 & 7 & 3 & $1-5$ & 2 \\
\hline & & Acasia sp. & 1 & 71.7 & 7 & 2 & 8 & 2 \\
\hline & Riausilip & A. heterophyllus & 1 & 20.1 & 6.8 & 2 & 7 & 1.2 \\
\hline & & T. сасао & 1 & 31.6 & 7 & 2 & 1 & 2 \\
\hline \multirow[t]{2}{*}{ D. rafflesiana } & Nangka Island & S. baccatum & 3 & 24.9 & 6.7 & 2 & $1-5$ & 1.2 \\
\hline & & D. zibethinus & 2 & 68.5 & 6.9 & 2 & 8 & 2 \\
\hline \multirow[t]{4}{*}{ D. hirsuta } & Petaling & Macaranga sp. & 4 & 37.5 & 7 & 3 & $6-7$ & 1 \\
\hline & & A. integer & 1 & 82.3 & 6.8 & 2 & 3 & 1 \\
\hline & Mangkol & T. obovata & 4 & 19.7 & 7 & 3 & 0.6 & 1 \\
\hline & & L. resinosa & 2 & 35.4 & 7 & 3 & 5 & 1 \\
\hline \multirow[t]{2}{*}{ D. bengalensis } & Kemuja & T. merguensis & 1 & 20.5 & 7 & 1 & $0.5-1$ & 1 \\
\hline & & Calophyllum sp. & 1 & 21.1 & 6.9 & 3 & 1.5 & 1 \\
\hline
\end{tabular}

Note: $\quad \mathrm{TP}=$ height of Dischidia position on host; $\mathrm{D}=$ diameter; $\mathrm{pH}=\mathrm{pH}$ of bark; $\mathrm{TK}=$ level of roughness (crude and cracked $=3$, slightly crude and slightly cracked = 2 fine $=1$ ); LT = position of Dischidia at host part (branch $=1$, main stem $=2$ )

trees with a slightly acidic to neutral pH level [23].

Furthermore, the location (stem and branch) in which Dischidia species are grown also affected their growth. Mostly, Dischidia was found at the branch of host tree. In addition, the level of roughness also affects the abundance of Dischidia. The rougher the surface of a rod, the higher the chance of epiphytic growth. Ewusie (1990) found that skin characteristics (rough, groove, slit) could improve growth of epiphytic plants [25]. The need for high environmental conditions to lie in the diverse host trees allows for significant epiphytic species linkage with the host tree, while rather slippery skin of the host tree will cause plants to stick and grow on the tree [26].

\section{Other epiphytic plants around Dischidia}

Nine species of epiphytes were found coexist with Dischidia. Asplenium nidus epiphytic plants (27 individuals), is the dominant epiphytes found in the host tree Dischidia (Figure 6). A. nidus occupies many species of host trees because it has a good adaptation in the condition of shady forest, exposed to partial or complete sunlight [24]. In addition, 25 individuals of Orchidaceae epiphytes were also found in the host tree Dischidia. 


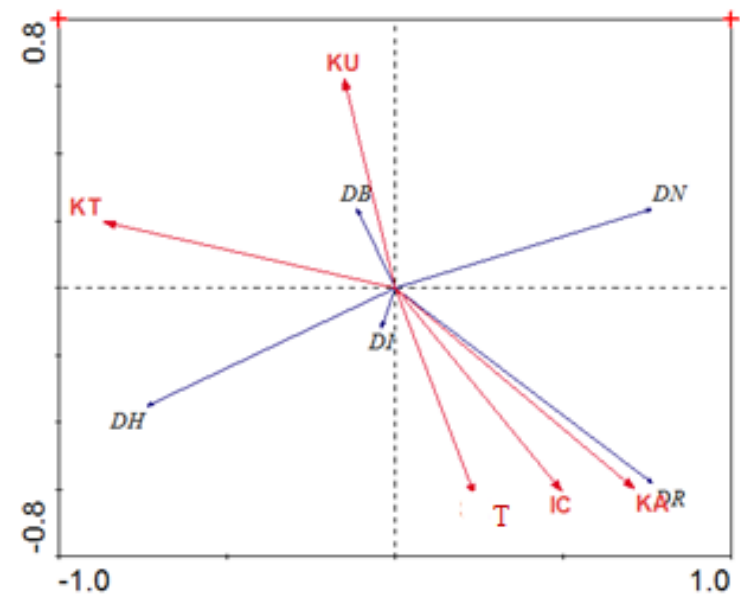

Figure 5. Correlation analysis of abiotic factor to the abundance of Dischidia. KA: wind speed; IC: light intensity; T: temperature; KT: altitude; KU: humidity; DR: D. rafflesiana; DN: D. nummularia; DH: D. hirsute; DB: D. bengalensis; DI: D. imbricate

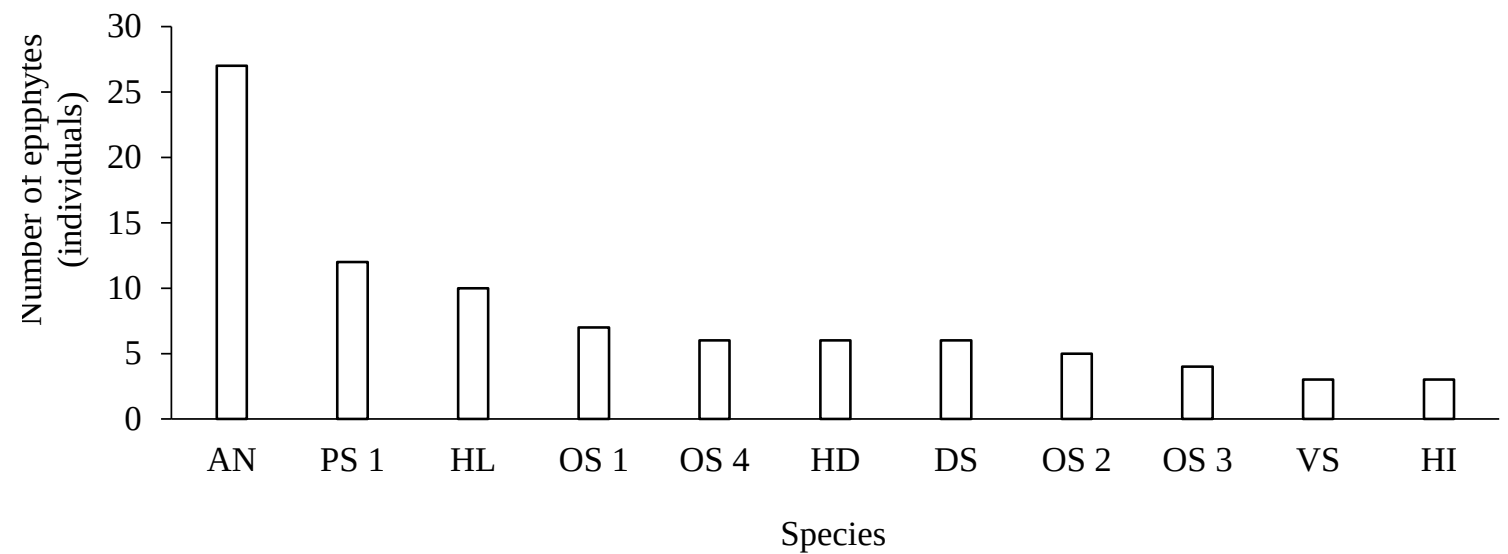

Figure 6. Total individuals of each epiphytic species found in Dischidia host from all plots at all sites. AN. Asplenium nidus, PS 1. Paku spesies 1, HL. Hoya lacunosa, OS 1. Orchidaceae sp.1, OS 4. Orchidaceae sp.4, HD. Hoya diversifolia, DS. Dendrobium sp., OS 2. Orchidaceae sp.2, OS 3. Orchidaceae sp.3, VS. Vanda sp., HI. Hoya imprealis.

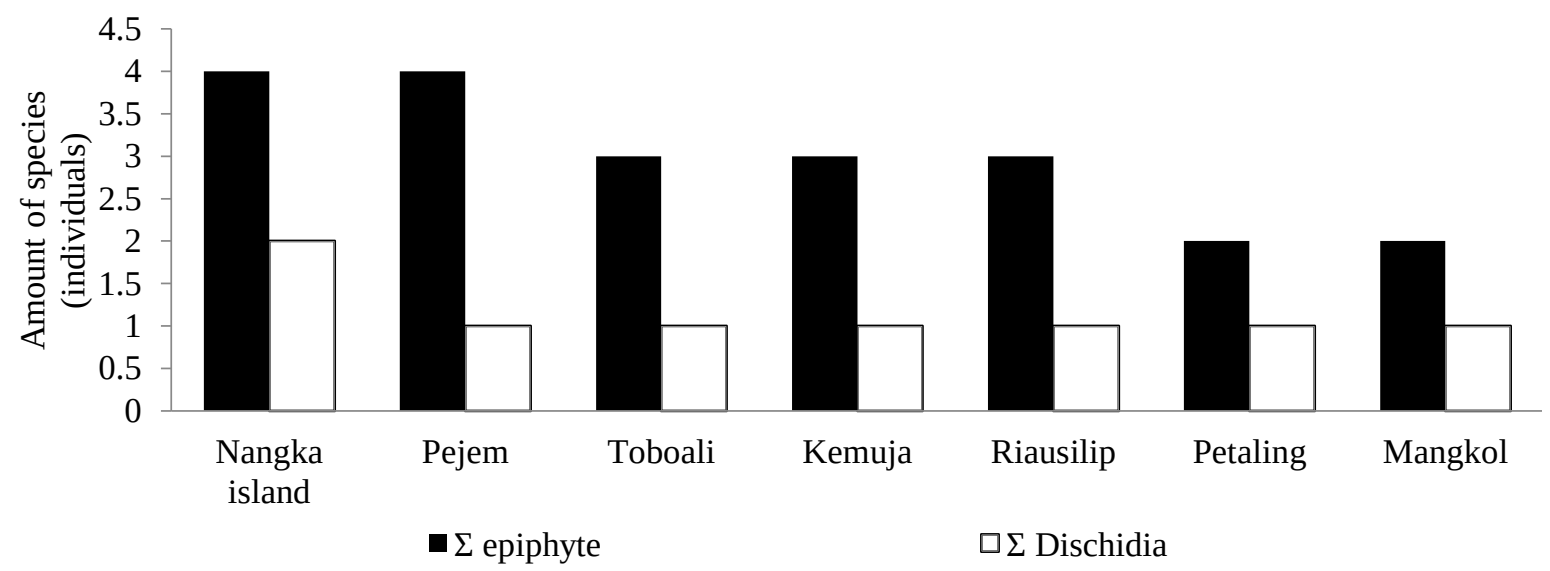

Figure 7. Comparison of the number of Dischidia species and number of the other epiphytic species at each research 
Figure 7 shows that the number of epiphytic species in each location is higher when compared with the number of Dischidia species. The highest number of epiphytic species was found in heath forest of Pejem and Nangka islands (4 species for each location). Epiphytes are found living side by side with Dischidia and utilizing the same nutrients. However, neither of them interferes with each other.

\section{Conclusion}

Number of species of Dischidia were found in Bangka Island, i.e. D. bengalensis, D.imbricate, $D$. nummularia, D. rafflesiana, and D. hirsute. $D$. imbricate, the most abundant species (23 individuals), was found in the Pejem heath forest. The Dischidia that is found in secondary forest was only 2 - 7 individuals. Dischidia were found in 14 species of host plants i.e. D. zibethinus, $M$. indica, $B$. frutescens, Acacia sp., A. heterophyllus, T. cacao, Sapium baccatum, Macaranga sp., Artocarpus integer, Tristania obovata, Litsea resinosa, Tristaniopsis merguensis, and Calophyllum sp. Factors affecting the abundance of Dischidia are the intensity of light, temperature, and humidity.

\section{Acknowledgment}

The author thankful to the supervisor for providing financial support for this research.

\section{References}

1. Nuraini SK, Andrew JM, Bruce B (2012) Ekologi Papua. Jakarta, Yayasan Pustaka Obor.

2. Kleijn D, van Donkelaar R (2001) Notes on the taxonomy and ecology of the genus Dischidia (Asclepediaceae) in central Sulawesi. Blumea 46: 457 - 483.

3. Rahayu M, Siti S, Diah S, Suhardjono P (2006) Pemanfaatan tumbuhan obat secara tradisional oleh masyarakat lokal di Pulau Wawonii, Sulawesi Tenggara. Biodiversitas 7 (3): 245 - 250. doi: 10.13057/biodiv/d070310.

4. Nurrani L, Julianus K, Supratman T (2012) Kandungan bahan aktif dan toksisitas tumbuhan hutan asal Sulawesi Utara yang berpotensi sebagai obat. Jurnal Penelitian Hasil Hutan 32 (2) 123 - 138. doi: 10.20886/jphh.2014.32.2.123-138

5. Fakhri MF, Sulistyaningrum G, Nurnawati et al. (2015) Koevolusi antara tumbuhan Dischidia major dengan jenis semut $\mathrm{La}$ sius fuliginosus di kawasan hutan desa Jatinegara, Tegal, Jawa Barat. PhD Thesis. Universitas Negeri Jakarta.

6. Rodda M, Tran HD, Chiew PT et al. (2012) The rediscovery of
Dischidia hirsuta (Apocynaceae, Asclepiadoideae) in Singapore. Gardens’ Bulletin Singapore 64 (2): 293 - 299.

7. Livshultz T (2003) Dischidia cleistantha (Apocynaceae, Asclepiadoideae): A new Philippine endemic. Novon 13 (1): 89 - 96. doi: 10.2307/3393569.

8. Indrawan A, Sukatjo W (1984) Biologi dan penyebaran Dischidia rafflesiana wall pada tegakan jati. Laporan Proyek Peningkatan/Pengembangan Perguruan Tinggi. Bogor, Institut Pertanian Bogor.

9. Rodda M, Lee D, Mishak S (2015) Dischidia acutifolia (Apocynaceae, Asclepiadoideae) a new record for the Singapore flora. Gardens' Bulletin Singapore 67 (1): 29 - 33. doi: 10.3850/S2382581215000022.

10. Departement of National Botanic Gardens (2012) The national red list 2012 of Sri Lanka. Colombo, Biodiversity Secretariat of the Ministry of Environment and National Herbarium.

11. Whitten T, Sengil JD, Janzanul A, Nazaruddin H (1997) The Ecology of Sumatra. Singapore, Periplus.

12. Ginting P, Ratno B, Khalisah K (2014) Grim portrait of Bangka Belitung tin mining. Netherland, WALHI and Milieudefensie.

13. Destri, Fudola A, Harto, Kusnadi (2015) Survei keanekaragaman anggrek (Orchidaceae) di Kabupaten Bangka Tengah dan Belitung, Provinsi Kepulauan Bangka Belitung. Prosiding Seminar Nasional Masyarakat Biodiversitas Indonesia 1 (3): 509 - 514. doi: 10.13057/ /psnmbi/m010322.

14. Lestari T, Abdi Z, Widodo J, Yohanes (2008) The vegetation analize of ex-tin mining land in Rebo village, Bangka. Envioagro 2 (2): 1 - 28

15. Rugayah, Retnowati A, Windadri FI, Hidayat A (2004) Pengumpulan data taksonomi. In: Rugayah, Widjaja EA, Praptiwi eds. Pedoman pengumpulan data keanekaragaman flora. Bogor, Puslit Biologi LIPI.

16. Odum EP (1993) Dasar-dasar ekologi, Ed ke-3. Yogyakarta, Gajah Mada University Press.

17. Ludwig JA, Reynolds JF (1988) Statistical ecology. 2nd ed. London, Edward Arnold.

18. Leps J (1953) Multivariate analysis of ecological data using CANOCO. Cambridge, Cambridge University Press.

19. Albers F, Meve U (2002) Illustrated handbook of Succulent plants: Asclepiadaceae. Berlin, Springer.

20. Putra FP (2013) Evaluasi fungsi ekologis dan tingkat revegetasi lahan pascatambangtimah di Air Mungkui, Kabupaten Belitung. $\mathrm{PhD}$ Thesis. Institut Teknologi Bandung.

21. Magurran AE (1988) Ecological diversity and its measurement. London, British Library.

22. van Leeuwen R, van Leeuwen W (1911) On the distribution of the seeds of certain species of Dischidia by means of a species of ant: Iridomyrmex myrmecodiae Emery. KNAW Proceedings. 23. Bima AM, Asri CP (2011) Tipe morfologi dan anatomi kulit 
batang pohon inang anggrek epifit di petak 5 bukit Plawangan, Taman Nasional Gunung Merapi. Cianjur, Seminar Nasional HUT Kebun Raya Cibodas Ke-159.

24. Ewusie JY (1990) Pengantar ekologi tropika. Bandung, Institut Teknologi Bandung.
25. Sujalu AP (2008) Analisis vegetasi keanekaragaman anggrek epifit di hutan bekas tebangan, Hutan Penelitian Malinau (Mrf) -Cifor. Media Konservasi 13 (3): 1 - 9. 